\title{
MÁRKÁK, SZÍNEK, ILLÚZIÓK
}

\author{
Paraszt Márta - Papp János
}

\begin{abstract}
Absztrakt: A vásárlói magatartásra jellemző szelektív torzítás során a fogyasztó az elvárásaival összhangban értelmezi az adott termékről szerzett információkat. Ebből adódóan a termékről alkotott ítéletei ellentétesek is lehetnek annak valódi paramétereivel. Leemelhetünk az üzletben a polcról egy cikket - annak jobb tulajdonságaiban bízva - csak azért, mert annak szebb a színe vagy éppen azért, mert gyakrabban találkoztunk a márka nevével. Finomabbnak feltételezhetjük vagy akár érezhetjük egy nevesebb márka termékének vagy egy tetszetősebben szervírozott élelmiszer ízét. Lehetünk tehát „elöítéletesek” pl. a márka vagy a csomagolás színe alapján. A sztereotípiák felgyorsítják a döntéseinket, értékítéletünket, hasonló folyamat tapasztalható a márkaválasztás során is.

A Szent István Egyetem Agrár- és Gazdaságtudományi Karán - energiaitalokkal - végzett tesztek segítségével igazoltuk, hogy mind a márkák, mind pedig a „,csomagolás” (szükebben annak színe) hatással vannak a megkérdezettekre. A válaszokból kiderült, hogy ízletesebbnek tartják az ismertebb és jól pozícionált termékeket, valamint a megkérdezettek az általuk preferált színü poharukban szervírozott italokat kedvelték jobban.
\end{abstract}

Abstract: In the case of selective distortion characteristic of customer behavior, the consumer interprets the information obtained about the product in accordance with his expectations. As a result, judgments about a product may conflict with its true parameters. We can pick up an article from the shelf in the shop, entrusting it with better qualities - just because it has a more beautiful color or just because we have seen the brand name more often. We may suppose or feel the taste of a more renowned brand or a more deliciously-served food. So we can be "prejudiced" eg. based on brand or packaging color. Stereotypes accelerate our decisions, value judgments, and similar processes in brand selection.

With the help of tests on energy drinks at the Faculty of Agricultural and Economic Studies of Szent István University, we have confirmed that both brands and "packaging" (their color) affect the respondents. The responses have shown that the more well-known and well-positioned products are considered more delicious, and the respondents liked the drinks served in their preferred color glasses.

Kulcsszavak: szelektív torzítás, vakteszt, márka, színteszt, energiaital

Keywords: selective distortion, blind test, brand, colour test, energy drink

\section{Bevezetés}

A fogyasztói magatartás egyik jellemzője a szelektivitás. A szelektivitás segítheti, vagy éppen hátráltathatja az ingerek észlelését. Számtalan inger közül azokat észleljük elsősorban, ami iránt érdeklődést mutatunk. A szelektív figyelem mellett lényeges a szelektív torzítás müködése is (Bauer et al., 2016).

A szelektív torzítás arra való hajlam, hogy az információkat oly módon értelmezzük, amely összhangban áll előzetes nézeteinkkel. A fogyasztók gyakran hajlamosak az információ eltorzítására, hogy ne kerüljenek ellentmondásba várakozásaikkal (Russo et al., 1998). A torzítás több formában is megvalósulhat (Lehota, 2001), ezek közül kettőt kiemelve:

- a fogyasztó az egyik terméktulajdonságot egy másikból vezeti le;

- bizonyos terméktulajdonságokat az imázs alapján ítél meg.

A szelektivitás következtében a fogyasztó ítéletei ellentétesek lehetnek a termék valódi tulajdonságaival (Lőricz-Sulyok, 2017). 
Magunkból kiindulva, előfordul, hogy képesek vagyunk élőlények, tárgyak pozitív vagy negatív külső jellemzőit kivetíteni azok valamennyi tulajdonságára. Röviden, elöítéletesek vagyunk, más szóval torzítunk.

A fogyasztók hajlamosak arra is, hogy a jól ismert, sokak által kedvelt márkanevet a jobb minőség garanciájának tartsák. A márkákkal kapcsolatos fogyasztói meggyőzés erejét jól bizonyítja, ha egy kóstoltató vakteszt során a fogyasztók egyik csoportja anélkül kóstolja meg a terméket, hogy tudná a márkáját, míg egy másik csoport a márkák ismeretében végzi ugyanezt, és eredményként a fogyasztók (a tulajdonképpen) azonos termékekről eltérő véleményt alkotnak, az minden bizonnyal azt jelenti, hogy a márkáról alkotott meggyöződéseik miatt érzékelik másként azokat (Kotler-Keller, 2012).

Az első benyomás egy termékről nagymértékben függ annak vonzó külsejétől is, amit lehet vizuális elemekkel befolyásolni. Vizuálisan érzékeljük a termék színét, méretét, formáját. Nem vitás azonban, hogy a színeké a főszerep.

„Minden, amit látunk szín. A meglátás folyamatában a szín elsődleges tényező: előbb látjuk meg a színt, csak aztán bontakozik ki a forma." (Walter-Novák, 1927) Elfogadott tény, hogy a színek hatást fejtenek ki a központi idegrendszerre, így aktiválva pl. gondolatainkat (Tóbiás, 2010).

A színek emberi magatartásra gyakorolt hatását az orvostudomány és a pszichológia is behatóan vizsgálja, a megjelent publikációk alapján megfogalmazható, hogy a színek befolyásolják az ember agymüködését (Agárdi, 2010). A színpszichológiával foglalkozó kutatók pedig még személyiségjegyeinket is képesek feltárni kedvenc színünk alapján (Újvilágtudat, 2017).

Aslam (2006) szerint a színek megváltoztatják a tárgyak és szituációk jelentését, befolyásolják a vásárló felfogását. A HVG egy 2016-os cikkében arról számol be, hogy az SCA és nemzetközi higiéniai márkája, a Tork mérte fel, hogyan reagálnak a vendégek a különböző színekre: A kísérlet során 8 különböző színü helyiségben, a helyiség színével megegyezö italt és süteményt fogyasztattak a vizsgált személyekkel, közben pedig agyhullám-scanner segítségével mérték az agyi aktivitásukat. Az eredmény azt mutatta, hogy az egyes színek egyértelmü és ismétlődő hangulati és érzelmi mintákat váltanak ki. A színeket ezenkívül különböző étkezési típusokkal azonosították (HVG, 2016).

A színek szerepe a vásárlók befolyásolásában az áru csomagolásán keresztül is érvényesül.

„A színek jobban befolyásolják döntéseinket, mint gondolnánk. Sok esetben csak egy szín miatt döntünk az A opció mellett a B helyett. A legtöbb termékcsomagolás és reklám mögött egy jól megtervezett stratégia áll, amelyet kifejezetten a színek pszichológiájában jártas szakemberek építettek fel. A piackutatók azt találták, hogy a színek jelentősen befolyásolják az emberek vásárlási szokásait, és míg az impulzív személyeket inkább a piros, a narancssárga, a fekete és a kék színek ösztönzik vásárlásra, addig azokat, akik alaposabban megfontolják döntésüket a vásárlás elött, a rózsaszín, a világoskék és a tengerkék színek." (Cégarculat, 2017) 
Több pszichológiai kísérlet bebizonyította, hogy a fogyasztók a termék minőségét és ízét bizonyos fokig a csomagolás szerint ítélik meg.

Hofmeister-Tóth (2006) arról ír, hogy Dézsi Lajos 1968-ban lefolytatott vizsgálatában igazolta a csomagolás színe és a termék ízének megítélése közötti összefüggést. A vizsgálatban azonos márkájú (ízű, minőségü) csokoládészeleteket csomagoltak tíz különböző színü sztaniolpapírba, 8, illetve 12 éves gyermekekkel kóstoltatták végig azokat. A gyermekek 83\%-a azt nyilatkozta, hogy a megkóstolt szeletek közül az általa kiválasztott színü ízletesebb volt a többinél. Hasonló kutatást végzett Dichter, melynek eredményeként összefüggést vélt felfedezni a kávé ízének és zamatának, illetve a kávéscsésze színe között.

Charles Spence, az Oxfordi Egyetem pszichológia professzora kutatásai során megállapította, hogy egy eper ízủ mousse tíz százalékkal édesebb, ha egy fehér tányérban szervírozzák, mint egy feketében; hogy a kávé csaknem kétszer olyan intenzív, de csak kétharmad olyan édes, ha egy fehér bögréből itták, és nem egy tiszta üvegcsészéből. (Twilley, 2015)

A színek hangulatot fejeznek ki, figyelmet keltenek, de akár befolyásolnak és manipulálnak is (Török, 2019). Manipulálhatnak oly mértékben, hogy képesek az ízérzetek megváltoztatására is.

A fogyasztói magatartás és az értékek változásait trendek segítségével követhetjük nyomon. Töröcsik (2016) trendek és ellentrendek összefoglaló táblázatában első helyen jelenik meg az ,idő és tempó” témacsoport, mely szerint az idő nyomására egyre „gyorsabban” élünk.

Forgács és Lehota (2018) az élelmiszerfogyasztói trendek között szintén felsorolták a „,rohanó, eszeveszett életmódot”. Trend, hogy kevesebb idő jut az ételek elkészítésére és fogyasztására. Ez vezethet ahhoz, hogy más étkezési szokásokat (pl. napi egyszeri étkezés, munka közben étkezés) veszünk fel vagy más termékeket/szolgáltatásokat választunk az étkezés során (pl. készételek- és italok).

Az emberek aktív idejüket szükösnek érzik, a növekvő feladatok elvégzéséhez szükséges teljesítmény fenntartására azonban szükség van stimuláló forrásokra. A rohanó életmód kiváltotta trendek és más okok teremtették meg az energiaitalok piacát.

Gradvohl et al. (2015) cikkében már 4 évvel ezelött arról olvashattunk, hogy Magyarországon és a világon az elmúlt években ugrásszerủen megnőtt az energiaital-fogyasztás a serdülők és a fiatal felnőttek körében.

A felsőoktatási intézmények hallgatói, illetve a dolgozó fiatalok az elsődleges célcsoportjai a termékkategóriának (Holicza-Tokody, 2016).

Az italokkal kapcsolatos elvárásaik között szerepel a fáradtság érzésének leküzdésére, illetve az energikusság, a felfrissülés, élénkítő hatás elérése - ebből adódóan a felpörgetettség, a teljesítmény fokozása. Legtöbben a tanulás és a munkavégzés alkalmával fogyasztják, amikor fontos számukra a jobb koncentrálóés teljesítőképesség. Azonban társas összejövetelek elmaradhatatlan kiegészítője is. (Dojcsákné Kiss-Tóth-Kiss-Tóth, 2018) 
Számukra a kávéfogyasztás modernizált változata. A kávéfogyasztás rituáléja már nem feltétlenül érték a mai, más ritmusban élő fiatalok számára, ők fogékonyabbak egy élénkítő, kellemes ízü, trendi italra (Válasz.hu, 2018).

Papp-Váry (2014) könyvében arról ír, hogy az energiaitalok (illetve bizonyos márkák) már a modern kori darabokban (Dr. Szöszi musical adaptációja), filmekben (SOS Szerelem), valóság-, illetve talkshow-ban, valamint klipekben is egyre gyakrabban jelennek meg.

A Világgazdaság Online (2017) egyik közéleti cikkében megjelent, hogy a fiatalok 59\%-a fogyaszt alkalmanként vagy rendszeresen energiaitalt. Egy évvel később pedig napvilágra hozták a Nielsen piackutató kiskereskedelmi adatait, mely szerint egy év alatt 44 millió liter energiaital fogyott hazánkban (Világgazdaság, 2018), valamint, hogy a kategória évek óta szerepel a Nielsen által mért élelmiszerkategóriák top20-as listáján.

A feldolgozott szekunder forrásokban bemutatott összefüggéseket egy kiscsoportos minta segítségével, energiaitalokon teszteltük. A kutatás módszertanát jelentősen korlátozta az anyagi források hiánya, így a jelenlegi eredményeket próbavizsgálatnak tekintjük egy későbbi, nagyobb volumenü teszt megvalósításához.

A kiválasztott célsokaságra vonatkozóan az alábbi hipotézisek igazolását tüztük ki célul:

- H1: A legismertebb márkanévvel rendelkező energiaitalt feltételezik a legjobb ízűnek a fogyasztók, ezt vásárolnák meg.

- H2: A csomagolás (a pohár) színe befolyásolja a fogyasztóknak az energiaitalok ízéröl alkotott véleményét.

- H3: Az energiaital fogyasztók száma meghaladja azok számát, akik még soha nem próbálták ki az italt.

\section{Anyag és módszer}

\subsection{Anyag}

A vizsgált célsokaság ${ }^{7}$ a Szent István Egyetem Agrár és Gazdaságtudományi Karának hallgatói voltak. A mintavételi keret összeállítása a Kar Tanulmányi Osztályának segítségével történt, mely során az aktív hallgatók $\mathrm{ABC}$ sorrendbe állított névsorát bocsátották rendelkezésünkre, Excel munkafüzetben. Az aktív hallgatók száma 208 fö volt az adott félévben (2018/19. II. félév). A minta nagyságát 16 föben határoztuk meg.

A teszteket - a mai fogyasztói trendet is képviselö - energiaitalokon végeztük. Három különböző márkájú és árfekvésü, azonban - az összehasonlíthatóság érdekében - azonos, tutti-frutti ízesítésü terméket vontunk be a vizsgálatba (1.ábra). A Hell hazánk - 2009 óta - piacvezető energiaital márkája ${ }^{8}$, a RedBull teremtett 32

\footnotetext{
${ }^{7}$ A célsokaság azon elemeknek az összessége, melyre következtetéseket akarunk levonni.

${ }^{8}$ https://mlenergy.hu/rolunk/
} 
éve egy teljesen új termékkategóriát, az energiaitalt ${ }^{9}$, ebből adódóan a legnagyobb múlttal rendelkezö. A Spark a Tesco saját márkás terméke.

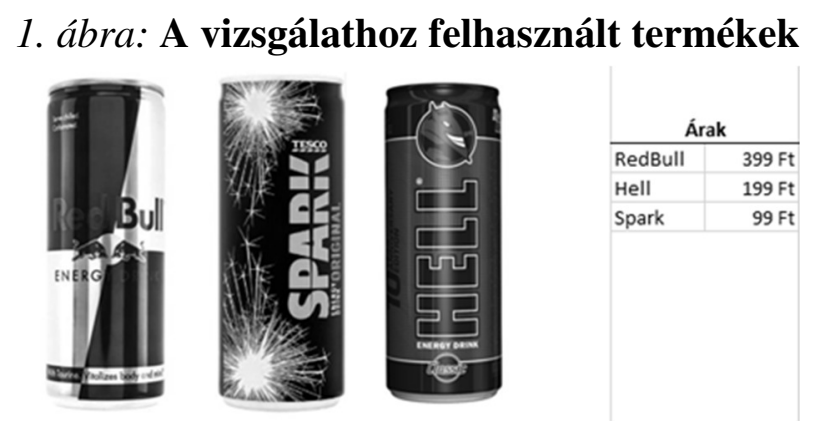

Forrás: A szerzők saját szerkesztése.

\subsection{Módszer}

A mintavételi módszerek közül a szisztematikus mintavételt ${ }^{10}$ választottuk. A sokaság elemeinek elrendezése ( $\mathrm{ABC}$ sorrend) nem volt összefüggésben a vizsgált jellemzőkkel. A mintavételi intervallum 13, az egyszerü véletlen mintavétellel meghatározott kezdő elem a 11.

A kiválasztott nappali tagozatos hallgatók felkeresése személyesen a Karon, a levelezősöké pedig a Tanulmányi Osztály által átadott e-mail elérhetőségen történt. A kutatásban való részvételt minden megkeresett hallgató vállalta.

A tesztek lebonyolítására 2019. február hónapban, előre egyeztetett időpontokban, 4 fős csoportokban került sor. A résztvevők egy azonosító sorszámot kaptak 1-16 között. Egy csoport két alkalommal (nem azonos napon) került tesztelésre.

Az első vizsgálat kezdő feladataként 6 kérdésre válaszoltak a csoport tagjai. A kérdések az energiaital fogyasztására, valamint a három bemutatott energiaital megítélésére vonatkoztak - kiemelten arra, hogy véleményük szerint, melyik terméknek a legjobb az íze, melyiket vennék meg. A második szakaszban került sor a vaktesztre ${ }^{11}$. A vaktesztek/íztesztek során a fogyasztók a 3 különbözö - általunk számmal kódolt - márkájú energiaitalt azonos, fehér színü, müanyag, számozott poharakban kóstolták, majd a pohár sorszámához - az ízletességre vonatkozóan helyezéseket rendeltek. Az eredményeket rögzítettük. Az utolsó szakaszban egy 10 színből álló papírcsomagból kellett a kedvenc, valamint a legkevésbé tetsző színt kiválasztaniuk, melyeket szintén rögzítettünk.

A második vizsgálat alkalmával a résztvevők - az általuk korábban kiválasztott - két különböző színű papírral borított pohárban felszolgált energiaitallal végeztek el

\footnotetext{
${ }^{9}$ https://energydrink-hu.redbull.com/red-bull-history

${ }^{10}$ A módszer a reprezentatív kiválasztás csoportjába tartozó véletlen mintavételi eljárás. Jellemzője, hogy minden egyes sokasági elem ismert és azonos valószínüséggel kerül kiválasztásra (Gyenge, 2009).

${ }^{11}$ Vaktesztnek hívjuk azt a kutatási keretet, amikor a termékteszt során minden márkaazonosítót leveszünk a termékről, úgy kínáljuk a célcsoport felé. (Veres et al., 2017)
} 
a színtesztet. Az élelmiszerekkel kapcsolatos színtesztek során alapvetően a színek és az ízek/aromák közötti összefüggéseket vizsgálják a kutatók. Az általunk folytatott vizsgálat célja az volt, hogy igazoljuk a (kedvenc) szín hatását a termék ízletességének megítélésére. A hallgatók - anélkül, hogy tudták volna - azonos márkájú energiaitalt fogyasztottak mind a két pohárból. A feladat annak meghatározása volt, hogy melyik színü pohárban található italt érezték ízletesebbnek.

A kérdésekre adott válaszokat, valamint a tesztek eredményeit Excel programban rögzítettük, az értékelés Excel és SPSS programok segítségével történt.

\section{Eredmények és értékelésük}

A megkérdezettek közül 4 fö nyilatkozott úgy, hogy még soha nem kóstolt korábban energiaitalt (ők a „,nem-fogyasztók”). Alkalomszerüen (havonta, illetve évente néhányszor) 8 fö fogyasztja, hetente akár többször is négyen élnek vele.

Tehát a résztvevők háromnegyede (12 fö, $75 \%)$ fogyasztónak ${ }^{12}$, míg a teljes minta negyede (4 fö, 25\%) rendszeres fogyasztónak ${ }^{13}$ tekinthetö (2. ábra, 2. oszlop). A vizsgálati eredmények további ismertetése során a havonta, illetve az évente néhány alkalommal fogyasztókat egy kategóriába (un. alkalomszerü fogyasztó) soroltuk.

\section{2. ábra: A kérdőíves vizsgálat eredményei (részlet)}

\begin{tabular}{c|c|c|c}
\multirow{2}{*}{$\begin{array}{c}\text { Válaszadó } \\
\text { sorszáma }\end{array}$} & $\begin{array}{c}\text { Milyen gyakran fogyaszt } \\
\text { energiaitalt? }\end{array}$ & $\begin{array}{c}\text { Melyik márkát feltételezi } \\
\text { a legízletesebbnek? } \\
\text { (Melyiket venné meg? }\end{array}$ & $\begin{array}{c}\text { Melyik márkát feltételezi a } \\
\text { legrosszabnak? (Melyiket } \\
\text { nem venné meg?) }\end{array}$ \\
\cline { 2 - 4 } & hetente akár többször is & Hell & Spark \\
\hline 1 & hetente akár többször is & Hell & Spark \\
\hline 2 & havonta & Hell & Spark \\
\hline 3 & soha & RedBull & Spark \\
\hline 4 & évente néhány alkalommal & Hell & Spark \\
\hline 5 & évente néhány alkalommal & RedBull & Spark \\
\hline 6 & évente néhány alkalommal & RedBull & Spark \\
\hline 7 & hetente akár többször is & Hell & Spark \\
\hline 8 & havonta & RedBull & Spark \\
\hline 9 & soha & RedBull & Spark \\
\hline 10 & havonta & RedBull & Spark \\
\hline 11 & soha & Hell & Spark \\
\hline 12 & hetente akár többször is & RedBull & Spark \\
\hline 13 & RedBull & Spark \\
\hline 14 & évente néhány alkalommal & Hell & Spark
\end{tabular}

Forrás: A szerzők saját szerkesztése.

A kóstoltatást megelőzően a válaszadók több mint fele (9 fö) a RedBull-nak, alig kevesebb, mint fele (7 fö) pedig a Hell-nek ítélte a „legjobb íz” címet, illetve ez az,

\footnotetext{
${ }^{12}$ Fogyasztónak azt tekintettük, aki fogyaszt valamilyen gyakorisággal energiaitalt.

13 Rendszeres fogyasztónak azt neveztem, aki hetente vagy hetente több alkalommal is iszik energiaitalt.
} 
amelyet meg is vásárolnának (2. ábra, 3. oszlop). Egyhangúan úgy feltételezték, hogy a Tesco saját márkás Spark termékének van a legkevésbé finom íze, így ez az, amelyet biztosan nem vennének meg (2. ábra, 4. oszlop).

\section{3. ábra: A RedBull-ra szavazók válaszai (részlet)}

\begin{tabular}{|c|c|c|c|c}
\multirow{2}{*}{$\begin{array}{c}\text { Válaszadó } \\
\text { sorszáma }\end{array}$} & $\begin{array}{c}\text { Milyen gyakran fogyaszt } \\
\text { energiaitalt? }\end{array}$ & $\begin{array}{c}\text { Melyik márkát } \\
\text { feltételezi a } \\
\text { legizletesebbnek? } \\
\text { (Melyiket venné } \\
\text { meg?) }\end{array}$ & $\begin{array}{c}\text { Miért gondolja, hogy ez a márka a } \\
\text { legfinomabb? }\end{array}$ & $\begin{array}{c}\text { Kifizetné-e a } \\
\text { piaci árát? }\end{array}$ \\
\hline 4 & alkalomszerũen & RedBull & legismertebb márka & nem \\
\hline 6 & alkalomszerũen & RedBull & legismertebb márka & igen \\
\hline 7 & alkalomszerũen & RedBull & legismertebb márka & nem \\
\hline 9 & alkalomszerũen & RedBull & legismertebb márka & nem \\
\hline 10 & soha & RedBull & legismertebb márka & igen \\
\hline 11 & alkalomszerũen & RedBull & legismertebb márka & igen \\
\hline 13 & soha & RedBull & legismertebb márka & igen \\
\hline 14 & alkalomszerũen & RedBull & legismertebb márka & igen \\
\hline 16 & soha & RedBull & legismertebb márka & nem \\
\hline
\end{tabular}

Forrás: A szerzők saját szerkesztése.

Megfigyelhetjük, hogy a RedBull-ra szavazók (3. ábra) csak a ,nemfogyasztók", illetve az alkalomszerüen fogyasztók közül kerültek ki. A ,nemfogyasztók"'-nak és az alkalmi fogyasztóknak is 75\%-a feltételezte a RedBullt a legfinomabbnak.

Ök azok, akik egyáltalán nem vagy csak kevesebb személyes tapasztalattal rendelkeznek a termékkategóriáról.

Mindannyian azt válaszolták, hogy azért várják a legjobb ízt ettől a márkától, mivel ez a legismertebb és legnagyobb márkanév a kategóriában.

A Hell ízének bizalmat szavazó 7 fő alapvetően a fogyasztók (rendszeresen vagy alkalomszerüen) kategóriájából került ki (4. ábra). A Hellt választók 85,7\%-a (6 fö) fogyasztónak minősül.

\section{4. ábra: A Hell-re szavazók válaszai (részlet)}

\begin{tabular}{c|c|c|c|c}
\multirow{2}{*}{\begin{tabular}{c} 
Válaszadó \\
\cline { 2 - 5 } sorszáma
\end{tabular}} & $\begin{array}{c}\text { Milyen gyakran fogyaszt } \\
\text { energiaitalt? }\end{array}$ & $\begin{array}{c}\text { Melyik márkát } \\
\text { feltételezi a } \\
\text { legízletesebbnek? } \\
\text { (Melyiket venné } \\
\text { meg?) }\end{array}$ & $\begin{array}{c}\text { Kiért gondolja, hogy ez a márka a } \\
\text { legfinomabb? }\end{array}$ & $\begin{array}{c}\text { Kifizetné-e a } \\
\text { piaci árát? }\end{array}$ \\
\hline 1 & rendszeresen & Hell & ismerem, jó az ize & igen \\
\hline 2 & rendszeresen & Hell & ismerem, jó az ize & igen \\
\hline 3 & alkalomszerũen & Hell & ismerốsök is ezt fogyasztják & igen \\
\hline 5 & soha & Hell & leggyakrabban találkozok a reklámjával & igen \\
\hline 12 & rendszeresen & Hell & ismerem, jó az ize & igen \\
\hline 15 & alkalomszerũen & Hell & ismerem, jó az ize & igen \\
\hline
\end{tabular}

Forrás: A szerzők saját szerkesztése. 
A rendszeres fogyasztók (4 fö) közül mindenki a Hellt választotta. Ök azok, akik jobban ismerik az energiaitalokat és valószínüleg már több márkát is kipróbáltak, esetleg márka hủek. Ezt támasztja alá az is, hogy a rendszeresen fogyasztók válaszukat azzal indokolták, hogy ,ismerik a márkát és elégedettek az ízével”.

Az alkalomszerüen fogyasztók (2 fö) pedig abból következtettek a jó ízre, hogy az ismerősök kezében mindig a Hellt látják, valamint, hogy ennek találkoznak a leggyakrabban a reklámjával. Ez utóbbival indokolta válaszát az az egy fö is, aki a „,nem-fogyasztó"-ként a Hellt választotta volna.

Az előzőekben bemutatott adatok alapján feltételezhetjük, hogy kapcsolat van a fogyasztás gyakorisága és a márkaválasztás (legjobb ízünek feltételezett márka) között. Ennek igazolására kereszttábla elemzést végeztünk ${ }^{14}$.

\section{5. ábra: A Khi-négyzet próba}

\begin{tabular}{|c|c|c|c|}
\hline \multicolumn{4}{|c|}{ Chi-Square Tests } \\
\hline & Value & df & $\begin{array}{l}\text { Asymp. Sig. } \\
\text { (2-sided) }\end{array}$ \\
\hline Pearson Chi-Square & $6,857^{\mathrm{a}}$ & 2 & 032 \\
\hline Likelihood Ratio & 8,434 & 2 &, 015 \\
\hline $\mathrm{N}$ of Valid Cases & 16 & & \\
\hline
\end{tabular}

Forrás: A szerzők saját szerkesztése.

A Khi-négyzet (Pearson Chi-Square) mutató értéke 6,857, ez 0,032 szignifikanciaszinten - mely kisebb az általunk választott 5\%-nál $(0,05)$ meghaladja az elméleti küszöbértéket $(5,99)$. A valószínúségi hányados (likelihood ratio) alapján szintén szignifikáns $(0,015<0,05)$ a kapcsolat. (5. ábra) Ebből adódóan a nullhipotézist elvetjük, van kapcsolat a két változó között ${ }^{15}$.

${ }^{14}$ A két változó közötti összefüggésre Pearson-féle Khi-négyzet próbát végeztünk. A kapcsolat erősségének meghatározására alkalmazható mutatók közül az aszimmetrikus mutatókat választottuk (Lambda, Goodman, Kruskal tau, bizonytalansági együttható), mivel a változók közötti (függetlenfüggő) viszony logikai úton eldönthető. A mutatószámok azt mérik, hogy a független változó (esetünkben: fogyasztási gyakoriság) milyen mértékben képes a függő változót (esetünkben: márka) elöre jelezni (Sajtos-Mitev, 2007).

${ }^{15}$ A Khi-négyzet statisztika kritériumai azonban sérülnek, mivel a cellák több, mint 20\%-nál a várható érték nem haladja meg az ötöt. Így ennek használata nem helyénvaló. Ennek kiküszöbölésére használjuk a Likelihood Ratiot. 


\section{6. ábra: A kapcsolat erősségének vizsgálata}

\begin{tabular}{|c|c|c|c|c|c|c|}
\hline \multicolumn{7}{|c|}{ Directional Measures } \\
\hline & & & Value & $\begin{array}{c}\text { Asymp. Std. } \\
\text { Error }\end{array}$ & Approx. $T^{b}$ & Approx Sig. \\
\hline \multirow[t]{8}{*}{ Nominal by Nominal } & \multirow[t]{2}{*}{ Lambda } & Symmetric & .400 & .219 & 1.512 & .131 \\
\hline & & VAR00001 Dependent & 250 & .265 &, 834 & .404 \\
\hline & $\mathbf{z}$ & VAR00002 Dependent & .571 & .187 & 2,309 & .021 \\
\hline & \multirow{2}{*}{$\begin{array}{l}\text { Goodman and Kruskal } \\
\text { tau }\end{array}$} & VAR00001 Dependent & .200 & .128 & & $.050^{\circ}$ \\
\hline & & VAR00002 Dependent & .429 & .163 & &, $040^{\circ}$ \\
\hline & \multirow[t]{2}{*}{ Uncertainty Coefficient } & Symmetric & .306 & .127 & 2,319 & $.015^{d}$ \\
\hline & & VAR00001 Dependent &, 253 &, 102 & 2,319 &, $015^{d}$ \\
\hline & $\Sigma$ & VAR00002 Dependent & .385 & .168 & 2.319 & $.015^{\mathrm{d}}$ \\
\hline
\end{tabular}

Forrás: A szerzők saját szerkesztése.

A lambda szerint $57,1 \%$-kal, a Goodman Kruskal tau szerint 42,9\%-kal, míg a bizonytalansági mutató alapján 38,5\%-kal javítja a fogyasztás gyakoriságának ismerete a márkaválasztásra vonatkozó becslést (6. ábra). 5\%-os szignifikancia szinten valamennyi mutató szignifikáns.

Azt követően, hogy ismertettük az egyes márkák árait, a legdrágább RedBull-ra szavazóknak már csak fele (4 fö) nyilatkozta azt, hogy így is ezt a márkát emelnék le a polcról (3. ábra, 5. oszlop). A RedBullt választó „,nem-fogyasztók” 67\%-a, míg az alkalmi fogyasztóknak már csak 50\%-a fizette volna meg a magasabb összeget.

A Hell-re voksolók esetében mindenki elfogadhatónak tartotta az árat (4. ábra, 5. oszlop).

7. ábra: Az ízteszt és a színteszt összefoglaló eredményei

\begin{tabular}{|c|c|c|c|c|c|c|}
\hline \multirow{3}{*}{$\begin{array}{l}\text { Válaszadó } \\
\text { sorszáma }\end{array}$} & \multicolumn{2}{|c|}{ Kérdések } & \multicolumn{3}{|c|}{ Ízteszt } & \multirow{3}{*}{$\begin{array}{l}\text { Szinteszt } \\
\text { Kedvenc } \\
\text { szinben a } \\
\text { finomabh }\end{array}$} \\
\hline & $\begin{array}{c}\text { Milyen gyakran fogyaszt } \\
\text { energiaitalt? }\end{array}$ & $\begin{array}{c}\text { Melyik márkát } \\
\text { feltételezi a } \\
\text { legizzletesebbnek? }\end{array}$ & \multirow[t]{2}{*}{ I. hely } & II. hely & \multirow[t]{2}{*}{ III. $h$} & \\
\hline & $\nabla$ & (Melyiket venné meg & & 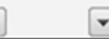 & & \\
\hline 1 & rendszeresen & Hell & Spark & Hell & RedBull & igen \\
\hline 2 & rendszeresen & Hell & Spark & Hell & RedBull & ugyanolyan \\
\hline 3 & alkalomszerũen & Hell & Spark & Hell & RedBull & igen \\
\hline 4 & alkalomszerũen & RedBull & Hell & Spark & RedBull & ugyanolyan \\
\hline 5 & soha & Hell & Spark & Hell & RedBull & ugyanolyan \\
\hline 6 & alkalomszerũen & RedBull & Hell & RedBull & Spark & igen \\
\hline 7 & alkalomszerũen & RedBull & RedBull & Hell & Spark & igen \\
\hline 8 & rendszeresen & Hell & Hell & Spark & RedBull & ugyanolyan \\
\hline 9 & alkalomszerũen & RedBull & Spark & RedBull & Hell & ugyanolyan \\
\hline 10 & soha & RedBull & RedBull & Hell & Spark & igen \\
\hline 11 & alkalomszerũen & RedBull & Hell & RedBull & Spark & igen \\
\hline 12 & rendszeresen & Hell & Hell & Spark & RedBull & ugyanolyan \\
\hline 13 & soha & RedBull & Spark & Hell & RedBull & ugyanolyan \\
\hline 14 & alkalomszerũen & RedBull & Spark & RedBull & Hell & igen \\
\hline 15 & alkalomszerũen & Hell & Spark & Hell & RedBull & igen \\
\hline 16 & soha & RedBull & Hell & RedBull & Spark & igen \\
\hline
\end{tabular}

Forrás: A szerzők saját szerkesztése.

A vaktesztek eredményeinek értékelése során a visszakódolt márkák helyezéseit pontszámokkal láttuk el. Az első hely 3, a második 2, a harmadik pedig 1 pontot kapott. 
Az összesítés során az alábbi eredmények születtek: a Hell 36 pontot ért el mellyel a legfinomabbnak ítélték a hallgatók, egy ponttal lemaradva a Spark 35 pontot, végül a RedBull 25 pontot szerzett az ,,́zversenyben”. A legjobbnak feltételezett RedBull vereséget szenvedett, a legsilányabbnak ítélt Spark alig csúszott le az első helyről (8. ábra).

\section{8. ábra: Az ízteszten elért helyezések és pontszámok}

\begin{tabular}{l|c|c|c|c} 
Márka/Helyezés & I. hely & II. hely & III. hely & Pontszám \\
\hline Hell & 6 & 8 & 2 & 36 pont \\
\hline RedBull & 2 & 5 & 9 & 25 pont \\
\hline Spark & 8 & 3 & 5 & 35 pont
\end{tabular}

Forrás: A szerzők saját szerkesztése.

A színtesztek során kilencen titulálták ízletesebbnek a kedvenc színủ poharukból fogyasztott energiaitalt, heten pedig - helyesen - úgy érezték, hogy ugyan az a márka található mind a két pohárban (7. ábra).

Megvizsgáltuk a fogyasztás gyakorisága, valamint a szín befolyásoló ereje közötti összefüggést. A Khi-négyzet (Pearson Chi-Square) mutató értéke 2,794, mely kisebb a viszonyítási küszöbértéknél. A valószínüségi hányados (likelihood ratio) alapján szintén nem szignifikáns $(0,236<0,05)$ a kapcsolat. (9. ábra) Ebből adódóan a nullhipotézist elfogadjuk, nincs kapcsolat a két változó között.

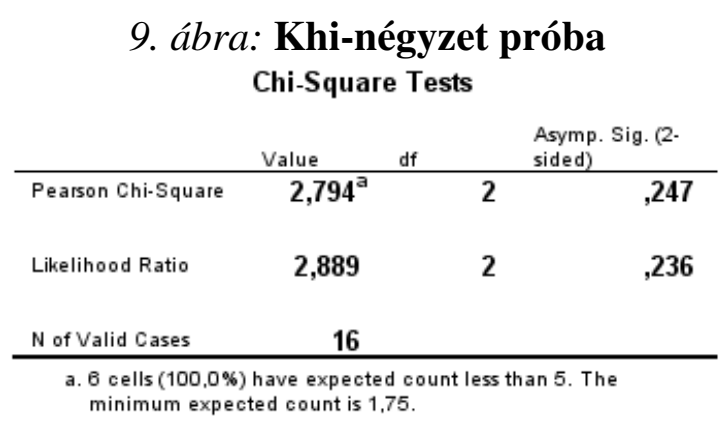

Forrás: A szerzők saját szerkesztése.

\section{4. Összegzés}

Kutatásunk célja a márkákkal, valamint a színekkel kapcsolatos sztereotípiák vizsgálata volt. A kutatás a Szent István Egyetem szarvasi karának hallgatói körében, kiscsoportos mintán, energiaitalokkal történt. A márkákkal kapcsolatos elöítéletek bemutatására íztesztet, a színekkel kapcsolatosan pedig színtesztet végeztünk.

Elért eredményeinket módszertani kiindulópontnak tekintjük egy nagyobb méretü kutatás megalapozásához. A vizsgálatok eredményeiből nem kívánunk általánosításokat levonni, azokat kizárólag az adott célsokaságra vonatkozóan fogalmaztuk meg:

- H1 hipotézist elfogadtuk. A legismertebb márkanévvel rendelkező energiaitalt (egyben a legrégebbi energiaital márkát) feltételezték a legízletesebbnek a teszt résztvevői. Megállapítottuk továbbá, hogy ez a 
feltételezés összefügg a fogyasztás gyakoriságával: elsősorban azokra igaz, akik kevesebb személyes tapasztalattal rendelkeznek a termékkategóriáról.

- H2 hipotézis megerősítést nyert. A hallgatók több mint fele érezte kellemesebbnek a kedvenc színü poharából fogyasztott italt. Nem találtunk kapcsolatot a fogyasztás gyakorisága, valamint a szín befolyásoló ereje között.

- H3 hipotézist támasztja alá, hogy a vizsgált személyek háromnegyede (alkalmi vagy rendszeres) energiaital fogyasztónak minősül.

\section{Irodalomjegyzék}

Agárdi I. (2010): Kereskedelmi marketing és menedzsment. Akadémiai Kiadó, Budapest, 296.

Aslam M. (2006): Are You Selling the Right Colour? A Cross-cultural Review of Colour as a Marketing Cue. Journal of Marketing Communications, 12 (1): 15-30.

Bauer A., Berács J., Kenesei Zs. (2016): Marketing alapismeretek. Akadémiai Kiadó, Budapest

Cégarculat (2017): Hogyan hatnak a színek a marketingben, avagy egy kis pszichológia a dizájnban, <http://cegarculat.hu/hogyan-hatnak-a-szinek-a-marketingben/>. (2019.03.28.)

Dojcsákné Kiss-Tóth É., Kiss-Tóth E. (2018): Energiaital fogyasztási szokások és egészségtudatosság a felsőfokú képzésben résztvevő hallgatók körében. Egészségfejlesztés, 59 (4): 17-26.

Forgács Cs., Lehota J. (2018): Élelmiszer marketing. In: Mizik T. (szerk): Agrárgazdaságtan II.. Akadémiai Kiadó, Budapest. <https://mersz.hu/hivatkozas/dj335agt_119\#dj335agt_119>. (2019.03.22.)

Gradvohl E., Vida K., Rácz J. (2015): Tölts rá...! Az alkohol és energiaital együttes fogyasztásának és a kockázatvállaló magatartási formák kapcsolatának felmérése fiatal felnőttek körében. Orvosi Hetilap, 156 (27): 1100-1108.

Gyenge B. (2009): Marketingkutatás. Szent István Egyetemi Kiadó, Gödöllő, 161.

Hofmeister-Tóth Á. (2006): A fogyasztói magatartás. Aula Kiadó, Budapest, 161-162.

Holicza P., Tokody D. (2016): Marketingmenedzsment a Magyar Piacon: A Hell Energy Esettanulmány. In: Bumbalová M., Cifranič M., Gubáňová M., Hanáčková D., Valach M. (szerk.): Legal, Economic, Managerial and Environmental Aspects of Performance Competencies by Local Authorities. Slovak University of Agriculture, Nyitra, 111-117.

HVG (2016): A színek pszichológiája: a kék nyugtat, a zöld regenerál, a piros inspirál, a fekete untat, <https://hvg.hu/plazs/20160223_A_szinek_pszichologiaja_a_kek_nyugtat_a_zold_regen eral_a_piros_inspiral_a_fekete_untat>.(2019.03.25.)

Kotler-Keller (2012): Marketingmenedzsment. Akadémiai Kiadó, Budapest, 193.

Lehota J. (2001): Az élelmiszer-vásárlói és -fogyasztói magatartás rendszere. In: Lehota J. (szerk.): Élelmiszer-gazdasági marketing. Müszaki Könyvkiadó, Budapest, 42.

Lőrincz K., Sulyok J. (2017): Turizmusmarketing. Akadémiai Kiadó, Budapest. <https://mersz.hu/ hivatkozas/dj277tm_41_p9\#dj277tm_41_p9>.(2019.03.13.)

Papp-Váry Á. (2014): Márkázott szórakoztatás. Akadémiai Kiadó, Budapest. <https://mersz.hu/do kumentum/dj142msz__1/>. (2019.03.11.)

Russo J. E., Meloy M. G., Medvec V. H. (1998): Predecisional Distortion of Product Information. Journal of Marketing Research, 35 (4): 438-452.

Sajtos L., Mitev A. (2007): SPSS Kutatási és adatelemzési kézikönyv. Alinea Kiadó, Budapest.

Tóbiás R. (2010): Az érzékszervek szerepe a marketingben. BGF Szakdolgozat, 34.

Törócsik M. (2016): Fogyasztói magatartás: Insight, trendek, vásárlók. Akadémiai Kiadó, Budapest. <https://mersz.hu/hivatkozas/dj72fm_9\#dj72fm_9>.(2019.03.22.)

Török J. (2019): A reklám szemiotikája. <http://www.communicatio.hu/doktoriprogramok/kommun ikacio/cikkek/torok_judit/torok_judit_a_reklam_szemiotikaja.pdf>. (2019.02.26.)

Twilley N. (2015): Accounting for Taste: How packaging can make food more flavorful. <https://www.newyorker.com/magazine/2015/11/02/accounting-for-taste>. (2019.03.02.) 
Újvilágtudat (2017): A színek pszichológiája - Hogyan befolyásolják a különbözö színek az érzékelésünket. <https://ujvilagtudat.blogspot.com/2017/11/a-szinek-pszichologiaja-hogyan.ht $\mathrm{ml}>$. (2019.03.28.)

Válasz.hu (2018): Megduplázni a bravúrt. <http://valasz.hu/magyarokapiacon/megduplazni-a-bravu rt-128794>. (2019.03.11.)

Veres Z., Hoffmann M., Kozák Á. (2017): Bevezetés a piackutatásba. Akadémiai Kiadó, Budapest. <https://mersz.hu/hivatkozas/dj219bap_69_p9\#dj219bap_69_p9>. (2019.03.21.)

Világgazdaság (2018): Egy év alatt 44 millió liter energiaitalt ittunk. <https://www.vg.hu/kozelet/ kozeleti-hirek/egy-ev-alatt-44-millio-liter-energiaitalt-ittunk-913529/>. (2019.03.11.)

Világgazdaság Online (2017): A lányok a kávét, a fiúk az energiaitalt kedvelik. <https://www.vg.hu /kozelet/lanyok-kavet-fiuk-az-energiaitalt-kedvelik-528910/>. (2019.03.11.)

Walter E., Novák L. (1927): A színek világa. <http://vmek.oszk.hu/10800/10859/10859.pdf>. (2019. 03.28.) 